\title{
Pengaruh variasi pemberian Snack bar ubi jalar kedelai hitam terhadap Kadar Superoksida Dismutase (SOD) darah
}

\author{
Fitriyono Ayustaningwarno ${ }^{1,2}$, Novita Sabuluntika ${ }^{1}$
}

\begin{abstract}
Background : Snack bar from sweet potatoes and black soybeans is low GI, fat and calorie snack which have antioxidant content, such as $\beta$-carotene, anthocyanin, isoflavone, and antioxidant activity, so can be an alternative snack for patients with DM type 2. Antioxidants intake can prevent the oxidative stress that lead micro-and macro-vascular complications in DM type 2. Antioxidant intake may preserve endogen antioxidant capacity, which is can be determined by analyzing SOD concentration.

Objective : analyze effect variety of Snack bar from sweet potatoes and black soybeans consume to SOD concentration.

Methods : experimental post-pretest research used 3 varieties of sweet potato's color (red, yellow, and purple) interventions. SOD concentration was analyzed by colorimetric. Statistic data was analyzed by dependent t-test and One Way Anova.

Results : No different between groups interventions Snack bar from purple, yellow or red sweet potatoes $(p=0,122)$. Group with snack bar from purple sweet potatoes intervention has lowest SOD decreasing percentage among other intervention groups.

Conclusion : Consume snack bar form purple sweet potatoes and black soybeans can preserve SOD concentration better than consume snack bar form yellow or red sweet potatoes and black soybeans
\end{abstract}

Keyword : Snack bar, sweet potato, black soybean, antioxidant, Superoxide Dismutase, SOD

\section{ABSTRAK}

Latar Belakang : Snack bar dari ubi jalar dan kedelai hitam mengandung Indeks Glikemik (IG) rendah dan makanan ringan yang mengandung antioksidan, seperti $\beta$-karoten, antosianin, isoflavon, dan aktivitas antioksidan. Snack bar tersebut dapat menjadi camilan alternatif untuk pasien dengan DM tipe 2. Asupan antioksidan dapat mencegah stres oksidatif yang menyebabkan komplikasi mikro dan makro-vaskular di DM tipe 2. Asupan antioksidan dapat meningkatkan kapasitas antioksidan endogen, yang dapat ditentukan dengan menganalisis konsentrasi Superoksida Dismutase (SOD).

Tujuan : Menganalisis pengaruh konsumsi berbagai Snack bar dari ubi jalar dan kedelai hitam terhadap konsentrasi SOD.

Metode : Penelitian eksperimental digunakan 3 jenis warna ubi jalar ini (merah, kuning, dan ungu) intervensi. Konsentrasi SOD dianalisis dengan kolorimetri. Data statistik dianalisis dengan bergantung t-test dan One Way Anova.

Hasil : Tidak ada perbedaan antara kelompok yang diintervensi Snack bar dari ubi jalar ungu, kuning atau merah $(p=$ 0.122). Kelompok dengan snack bar dari ubi jalar ungu intervensi mengalami persentase penurunan SOD terendah diantara kelompok intervensi lainnya.

Simpulan : Mengkonsumsi makanan ringan berupa bar ungu ubi jalar dan kedelai hitam dapat meningkatkan konsentrasi SOD lebih baik daripada mengkonsumsi ubi jalar makanan ringan berupa bar kuning atau merah dan kedelai hitam

Keyword : Snack bar, ubi jalar, kedelai hitam, antioksidan, Superoxide Dismutase, SOD

\section{PENDAHULUAN}

Snack bar ubi jalar kedelai hitam merupakan makanan selingan berbentuk batang dan berbahan baku ubi jalar dan kedelai hitam dengan variasi warna yakni snack bar ubi jalar ungu, kuning dan merah. Satu takaran saji $56 \mathrm{~g}$ snack bar ubi merah, kuning, ungu secara masing-masing mengandung 131,$89 ; 149,79 ; 142,30$ kkal energi, 30,86; 35,68; 33,32 g karbohidrat, 0,41; 0,$39 ; 0,43 \mathrm{~g}$ lemak, 1,$19 ; 0,897 ; 1,28 \mathrm{~g}$ protein, 1,74; 1,$66 ; 2,13 \mathrm{~g}$ serat, dan 10,$24 ; 13,89 ; 8,91 \mathrm{~g}$ amilosa.

\footnotetext{
${ }^{1}$ Program Studi Ilmu Gizi Fakultas Kedokteran

Universitas Diponegoro, Semarang 50231

${ }^{2}$ Center of Nutrition Research (CENURE), Universitas Diponegoro, Semarang 50231

Korespondensi dengan penulis
}

ayustaningwarno@fk.undip.ac.id
Karena menggunakan bahan pangan lokal ubi jalar dan kedelai hitam berindeks glikemik rendah serta kandungan gizi tersebut, snack bar ini dapat digunakan sebagai makanan selingan penderita diabetes melitus tipe 2 (DM tipe 2). ${ }^{1}$

Selain itu penderita diabetes DM tipe 2 membutuhkan asupan makanan yang mengandung antioksidan. Asupan makanan yang mengandung antioksidan diperlukan untuk mencegah terjadinya komplikasi pada penderita DM tipe-2, dimana kondisi hiperglikemia pada DM tipe-2 menyebabkan peningkatan produksi radikal bebas dan penurunan antioksidan endogen atau disebut dengan stres oksidatif. Stres oksidatif yang tidak ditanggulangi dengan antioksidan eksogen menyebabkan peningkatan resistensi insulin dan komplikasi makro 
maupun mikrovaskuler seperti penyakit kardiovaskuler dan diabetes nefropatik. ${ }^{2-5}$

Snack bar ubi jalar dan kedelai hitam mengandung antioksidan berupa $\beta$-karoten, isoflavon, antosianin dan aktivitas antioksidan. Masing-masing variasi snack bar memiliki kandungan antioksidan yang berbeda pula. Kadar $\beta$-karotensnack bar dengan ubi jalar ungu, yakni 144,5 $\mu \mathrm{g} / \mathrm{g}$,snack bar ubi jalar kuning 127,1 $\mu \mathrm{g} / \mathrm{g}$ dan snack bar ubi jalar merah 99,3 $\mu \mathrm{g} / \mathrm{g}$. $\beta$-karoten merupakan prekursor vitamin A serta berfungsi sebagai antioksidan sekunder.

Antioksidan sekunder merupakan antioksidan yang memiliki fungsi menangkap radikal bebas (radical scavengers) dan mencegah reaksi berantai, sehingga tidak terjadi peroksidasi lipid. Kadar antosianin snack bar ubi jalar ungu 56,29 mg/g,snack bar ubi jalar kuning $22,75 \mathrm{mg} / \mathrm{g}$ dan snack bar ubi jalar merah47,40 mg/g. Antosianin termasuk pigmen kelompok flavonoid yang menghasilkan warna jingga, merah dan biru bersifatlarut dalam air dan mudah mengalami degradasi.Antosianin dari kulit kedelai hitam mampu menurunkan kadar glukosa darah dengan meningkatkan kerja reseptor insulin, memperbaiki status antioksidan dengan menekan malondialdehid (MDA) sebagai penanda stres oksidatif serta memperbaiki level superoksida dismutase (SOD) dan katalase sebagai enzim-enzim antioksidan pada tikus diabetes. ${ }^{2}$

Kadar isoflavon snack bar ubi jalar ungu 18,669 mg/g protein,snack bar ubi jalar kuning 14,269 mg/g protein dan snack bar ubi jalar merah 10,975 mg/g protein. Isoflavon sebagai antioksidan primer, yakni mengeliminasi langsung oksigen radikal bebas dan meningkatkan konsentrasi enzim antioksidan. Isoflavon merupakan antioksidan golongan flavonoid yang biasa terdapat pada kedelai dan memiliki efek bermanfaat pada penderita DM dengan meningkatkan serum insulin dan komponen insulin pankreas. Aktivitas antioksidan snack bar ubi jalar ungu 40,23\%, snack bar ubi jalar kuning 24,90\% dan snack bar dengan ubi jalar merah. Aktivitas antioksidan merupakan parameter yang dapat menggambarkan persentase kemampuan suatu bahan makanan atau pangan dalam menghambat radikal bebas. ${ }^{2} \mathrm{~J}$ ika dikonsumsi, variasi kandungan antioksidan dalam snack bartersebut mungkinkan mempengaruhi kapasitas antioksidan dalam darah. Salah satu parameter yang dapat menggambarkan kapasitas antioksidan dalam darah adalah SOD. SOD merupakan enzim yang berperan sebagai antioksidan primer yang secara langsung dapat memberikan yang mampu memberikan atom hidrogen pada senyawa radikal secara cepat. ${ }^{6-9}$ Penelitian ini merupakan penelitian lanjutan yang bertujuan untuk menganalisis pengaruh variasi pemberian snack bar ubi jalar kedelai hitam terhadap kadar SOD.

\section{METODE DAN BAHAN}

Penelitian utama dengan rancangan acak satu faktor, yaitu tiga variasi warna ubi jalar, meliputi ubi jalar merah, ubi jalar kuning, dan ubi jalar ungu dengan menggunakan formulasi kedelai hitam $30 \%$. Bahan baku terdiri dari ubi jalar merah, ubi jalar kuning, dan ubi jalar ungu yang diperoleh dari Pasar Bandungan Ungaran, kedelai hitam diperoleh dari Pasar Gedhe Surakarta, premiks pemanis "Tropicana Slim Diabetics" produksi PT Nutrifood Indonesia, telur, susu skim bubuk, dan margarin.

Tepung ubi jalar yang digunakan merupakan tepung komersial produksi PT. Rejeki Berkah Gunung Pati Semarang dimana ubi jalar yang dipakai adalah ubi jalar yang diperoleh dari Pasar Bandungan. Alat yang digunakan dalam pembuatan snack bar antara lain; timbangan digital analitik, baskom, blender, mangkok, mixer, spatula, sendok, pyrex, dan microwave. Pembuatan snack bar terdiri dari ubi jalar dan kedelai hitam dicuci bersih, kemudian dikukus, ubi jalar dan kedelai kukus serta bahan tambahan lain dicampur menggunakan mixer, lalu dicetak ke dalam pyrex dan terakhir dipanggang menggunakan microwave.

Pengujian antioksidan darah dilakukan dengan parameter Superoksida dismutase (SOD). Kadar SOD sebelum dan setelah pemberian snack bar ubi jalar kedelai hitam dikumpulkan dengan pengambilan darah intravena 9 subjek oleh tenaga medis dari Prodia. Sebelum pengambilan darah subjek diharuskan puasa kecuali air putih selama 10 jam. Pemberian snack bar sebanyak $80 \mathrm{~g}$ setara dengan 200 kkal dilakukan selama tujuh hari. Subjek dibagi menjadi tiga kelompok, yakni kelompok yang diberikan snack bar ubi jalar ungu kedelai hitam, snack bar ubi jalar merah kedelai hitam dan snack bar ubi jalar kuning kedelai hitam. Pemilihan subjek merupakan subjek sehat, tidak sedang mengonsumsi jamu atau suplemen yang mengandung antioksidan, tidak merokok dan memiliki indeks massa tubuh normal, serta bersedia menjadi subjek penelitian melalui pengisian informed consent. Kadar SOD dianalisis dengan metode kolorimetri. ${ }^{10}$

\section{HASIL}

Karakteristik subjek terdiri dari gambaran umur dan status gizi subyek sebelum penelitian disajikan dalam tabel 1 . Hasil analisis recall asupan 24 jam disajikan dalam tabel 2. Pengaruh variasi pemberian snack bar 
terhadap kadar SOD dapat dilihat pada tabel 3 . Sedangkan korelasi antar parameter uji dapat diamati pada tabel 4 .

\section{PEMBAHASAN}

Subjek yang digunakan adalah individu sehat dengan rentang umur 21-22 tahun, status gizi normal, dan tidak merokok. Hasil uji beda tidak ada perbedaan umur, status gizi, kadar SOD, $\mathrm{Hb}$ dan $\mathrm{SOD} / \mathrm{Hb}$ awal $(\mathrm{p}>0,05)$. Sebelum dan selama intervensi dilakukan recall asupan 24 jam seperti pada tabel 3

Tabel 1. Karakteristik Subjek

\begin{tabular}{lcccc}
\hline \multirow{2}{*}{$\begin{array}{c}\text { Karaketristik } \\
\text { Subjek }\end{array}$} & $\begin{array}{c}\text { Snack bar ubi jalar ungu } \\
\text { dan kedelai hitam }(\mathrm{n}=3)\end{array}$ & $\begin{array}{c}\text { Snack bar ubi jalar kuning } \\
\text { dan kedelai hitam }(\mathrm{n}=3)\end{array}$ & $\begin{array}{c}\text { Snack bar ubi jalar merah } \\
\text { dan kedelai hitam }(\mathrm{n}=3)\end{array}$ & $\mathrm{P}$ \\
\cline { 2 - 4 } & Mean \pm SD & Mean \pm SD & Mean \pm SD & $0,67^{*}$ \\
Umur & $21,7 \pm 0,6$ & $21,7 \pm 0,6$ & $21,3 \pm 0,6$ & $0,47^{* *}$ \\
IMT & $21,0 \pm 1,0$ & $21,3 \pm 1,7$ & $20,0 \pm 1,0$ & $0,922^{* *}$ \\
SOD Pre & $248,7 \pm 12,9$ & $242,3 \pm 5,0$ & $252,7 \pm 52,8$ & $0,596^{* *}$ \\
Hb Pre & $13,9 \pm 0,35$ & $12,9 \pm 2,02$ & $12,9 \pm 0,96$ & $0,771^{* *}$ \\
SOD/Hb Pre & $1792,70 \pm 61,50$ & $1915,60 \pm 313,13$ & $1961,17 \pm 386,39$ & 0 \\
\hline
\end{tabular}

*Kruskal-wallis, **One-way Anova

Tabel 2 .Asupanenergi, protein, lemak, karbohidrat, dan vitamin A kelompok perlakuan

\begin{tabular}{|c|c|c|c|c|c|c|c|}
\hline \multirow{3}{*}{ Asupan } & \multicolumn{6}{|c|}{ Perlakuan } & \multirow[b]{3}{*}{$\mathrm{p}$} \\
\hline & \multicolumn{2}{|c|}{$\begin{array}{l}\text { Snack bar ubi jalar ungu } \\
\qquad(\mathrm{n}=3)\end{array}$} & \multicolumn{2}{|c|}{$\begin{array}{l}\text { Snack bar ubi jalar kuning } \\
(\mathrm{n}=3)\end{array}$} & \multicolumn{2}{|c|}{$\begin{array}{l}\text { Snack bar ubi jalar } \\
\text { merah }(\mathrm{n}=3)\end{array}$} & \\
\hline & Mean \pm SD & $\%$ RDA & Mean \pm SD & $\%$ RDA & Mean \pm SD & $\%$ RDA & \\
\hline Energi pre & $1088,4 \pm 538,3$ & 57,3 & $1684,3 \pm 388,4$ & 88,6 & $1451,3 \pm 66,7$ & & \\
\hline Energi post & $1311,8 \pm 162,2$ & 69,0 & $1341,1 \pm 156.9$ & 70,6 & $1360,6 \pm 205$ & 76,4 & \\
\hline$\Delta$ energi & $223,4 \pm 543,7$ & & $-343,2 \pm 292,8$ & & $-90,7 \pm 265,4$ & 71,6 & $0,277^{*}$ \\
\hline $\mathrm{p}$ & $0,550^{* *}$ & & $0,179^{* *}$ & & $0,614^{* *}$ & & \\
\hline Protein pre & $43,2 \pm 23,4$ & 60,6 & $68,2 \pm 42,5$ & 95,8 & $60,5 \pm 7,4$ & & \\
\hline Protein post & $38,0 \pm 12,7$ & 53,3 & $44,4 \pm 8,7$ & 62,4 & $42,0 \pm 2,8$ & 84,9 & \\
\hline$\Delta$ protein & $-5,2 \pm 16,6$ & & $-23,8 \pm 35,8$ & & $-18,4 \pm 6,1$ & 59,0 & $0,620^{*}$ \\
\hline $\mathrm{p}$ & $0,643^{* *}$ & & $0,369^{* *}$ & & $0,035^{* *}$ & & \\
\hline Lemak pre & $34,8 \pm 22,1$ & 65,8 & $75,1 \pm 25,5$ & 142,3 & $51,7 \pm 7,2$ & & \\
\hline Lemak post & $41,1 \pm 6,5$ & 77,9 & $43,3 \pm 3,0$ & 82,1 & $46,9 \pm 10,6$ & 98,0 & \\
\hline$\Delta$ lemak & $6,3 \pm 25,1$ & & $-31,8 \pm 25,8$ & & $-4,9 \pm 17,7$ & 88,8 & $0,197^{*}$ \\
\hline $\mathrm{p}$ & $0,705^{* *}$ & & $0,166^{* *}$ & & $0,681^{* *}$ & & \\
\hline KH pre & $14,6 \pm 66,3$ & 51,8 & $183,6 \pm 25,7$ & 64,4 & $183.6 \pm 3.8$ & & \\
\hline $\mathrm{KH}$ post & $197,8 \pm 15,5$ & 69,4 & $195,3 \pm 40,1$ & 68,5 & $193,7 \pm 26,1$ & 64,4 & \\
\hline$\Delta \mathrm{KH}$ & $50,1 \pm 68,2$ & & $11,7 \pm 20,8$ & & $-10,1 \pm 29,0$ & 68,0 & $0,500^{*}$ \\
\hline $\mathrm{p}$ & $0,331^{* *}$ & & $0,434^{* *}$ & & $0,608^{* *}$ & & \\
\hline Vit A pre & $2533,2 \pm 3878$ & 316,6 & $460.6 \pm 378.5$ & 57,6 & $846.0 \pm 365,0$ & & \\
\hline Vit A post & $1844,8 \pm 337,7$ & 230,6 & $1909,6 \pm 748,8$ & 238,7 & $2070,3 \pm 737$ & 105,7 & \\
\hline$\Delta$ Vit A & $-688,4 \pm 3686,3$ & & $1449 \pm 408,2$ & & $1224,2 \pm 984$ & 258,9 & \\
\hline $\mathrm{p}$ & $0,777^{* *}$ & & $0,025^{* *}$ & & $0,164^{* *}$ & & , $476^{*}$ \\
\hline
\end{tabular}

* one way anova, ** paired t test

RDA (Recommanded Dietary Allowance) untuk perempuan umur 19-24 tahun 
Tabel 3. Pengaruh variasi pemberian snack bar ubi jalar kedelai hitam terhadap superoksida dismutase (SOD)

\begin{tabular}{lcccc}
\hline & \multicolumn{4}{c}{ Perlakuan } \\
\cline { 2 - 4 } Variabel & $\begin{array}{c}\text { Snack bar ubi jalar ungu } \\
\text { dan kedelai hitam }(\mathrm{n}=3)\end{array}$ & $\begin{array}{c}\text { Snack bar ubi jalar } \\
\text { kuning dan kedelai } \\
\text { hitam }(\mathrm{n}=3)\end{array}$ & $\begin{array}{c}\text { Snack bar ubi jalar } \\
\text { merah dan kedelai hitam } \\
(\mathrm{n}=3)\end{array}$ & $\mathrm{p}$ \\
\hline SOD $(\mathrm{U} / \mathrm{ml} \mathrm{Hb})$ & $1792,7 \pm 61,50$ & $1915,6 \pm 313,13$ & $1961,2 \pm 386,39$ & \\
Pre & $1744,7 \pm 96,45$ & $1681,2 \pm 285,02$ & $1864,3 \pm 328,33$ & $0,122^{* *}$ \\
Pos & $-48,0 \pm 130,56$ & $-234,4 \pm 46,89$ & $-96,9 \pm 111,96$ & \\
$\Delta$ & $2,56 \pm 7,08$ & $12,27 \pm 2,03$ & $4,66 \pm 4,76$ & \\
Persen $\Delta(\%)$ & $0,589 *$ & $0,013 *$ & $0,273^{*}$ & \\
\hline \multicolumn{2}{c}{$\mathrm{p}$} & &
\end{tabular}

Tabel 4. Korelasi Kadar Antioksidan Pangan dan Kadar Antioksidan Darah

\begin{tabular}{lllllll}
\hline \multicolumn{1}{c}{ Variabel } & $\Delta$ SOD & $\begin{array}{c}\text { Persen } \Delta \\
\text { SOD }\end{array}$ & $\beta$ karoten & Antosianin & Isoflavon & $\begin{array}{c}\text { Aktivitas } \\
\text { antioksidan }\end{array}$ \\
\hline$\Delta$ SOD & 1.000 & $.933^{* * *}$ & .200 & .517 & .083 & .067 \\
Persen $\Delta$ SOD & & 1.000 & .100 & $.683^{*}$ & -.050 & .000 \\
$\beta$ karoten & & & 1.000 & .351 & $.918^{* *}$ & $.910^{* * *}$ \\
Antosianin & & & & 1.000 & $.464^{*}$ & $.510^{*}$ \\
Isoflavon & & & & 1.000 & $.906^{* * *}$ \\
Aktivitas antioksidan & & & & & & 1.000 \\
\hline
\end{tabular}

Keterangan : Analisis menggunakan uji Spearman, dengan nilai korelasi 0,80-1,00: sangat kuat; 0,60-0,799 : kuat; 0,40-0,599 : sedang; 0,20-0,399: lemah;0,00-0,199: sangat lemah.

Berdasarkan tabel 3 terdapat perbedaan asupan protein sebelum-selama pemberian pada kelompok perlakuan snack bar ubi jalar merah dan asupan vitamin A sebelum-selama pemberian pada kelompok snack bar kuning $(\mathrm{p}<0,05)$.

Berdasarkan tabel 4 tidak terdapat perbedaan kadar SOD dari masing-masing kelompok perlakuan ( $>>0,05)$. Terdapat pengaruh kadar SOD sebelum dan setelah intervensi pada kelompok pemberian snack bar ubi jalar kuning dan kedelai hitam $(\mathrm{p}<0,05)$. Pada akhir penelitian terjadi penurunan kadar SOD. Penurunan kadar SOD dapat diakibatkan penurunan asupan energi dan protein, dapat dilihat pada tabel 3. Penurunan asupan makanan dari rekomendasi asupan harian menyebabkan peningkatan katabolisme dalam tubuh. Peningkatan katabolisme dapat menimbulkan peningkatan produksi radikal bebas yang mengakibatkan pengambilan antioksidan endogen untuk menstabilkan radikal bebas tersebut dengan memberikan secara langsung senyawa elektronnya. Penurunan asupan proteindapat meningkatkan peroksidasi lipid dengan mempengaruhi sintesis SOD dimana protein berfungsi sebagai komponen pembentuk enzim. ${ }^{11}$

Penelitian ini hanya dilihat dari satu parameter yakni SOD, perlu dikaji parameter antioksidan yang lain seperti Glutation Peroksidase (GPX), katalase (CAT), dan status antioksidan total (SAT), serta malondialdehid (MDA). GPX dan CAT memiliki fungsi antioksidan endogen seperti SOD. Ketiga enzim tersebut bekerja saling berkesinambungan. Kemungkinan pada penelitian ini terjadi peningkatan enzim GPX atau katalase maupun penurunan MDA. ${ }^{12}$

Kelompok perlakuan dengan snack bar ubi jalar ungu mengalami penurunan SOD yang lebih rendah $(2,5 \%)$ daripada kelompok perlakuan snack bar ubi jalar kuning dan merah. Hal ini dapat disebabkan kandungan antioksidan pada snack bar ubi jalar ungu lebih tinggi daripada snack bar ubi jalar kuning dan merah. Untuk mengetahui besarnya korelasi antar variabel digunakan uji korelasi Spearman.

Berdasarkan tabel 5., kadar $\beta$-karoten dan isoflavon memiliki korelasi yang kuat terhadap aktivitas antioksidan. Semakin tinggi kadar $\beta$-karoten dan isoflavon semakin tinggi meningkatkan aktivitas antioksidan snack bar. Kadar antosianin memiliki korelasi sedang terhadap aktivitas antioksidan snack bar. Kadar SOD memiliki korelasi kuat dengan kandungan antosianin snack bar. Hal ini dapat disebabkan karena senyawa antosianin yang terkandung dalam snack bar ubi jalar kedelai hitam dapat mempertahankan kadar SOD dalam darah dengan memodulasi mRNA SOD hati. ${ }^{13,14}$

Hiperglikemia pada DM menyebabkan hiperglisolia atau keadaan dimanajaringan dan sel seperti kardiovaskuler, jaringan saraf, sel endotel 
pembuluh darah dan sel retina serta lensa yang memiliki kemampuan memasukkan glukosa ke dalam sel tanpa bantuan insulin (insulin independent), glukosa masuk tanpa terkendali ke dalam jaringan tersebut. Hiperglisolia mengakibatkan stres oksidatif, yakni kondisi yang berhubungan peningkatan kecepatan kerusakan sel akibat induksi oksigen dan turunannya (ROS atau Reactive Oxygen Species) karena ketidakseimbangan antara ROS yang dihasilkan dengan sistem penangkapan radikal (antioksidan endogen). ${ }^{3}$ Stres oksidatif meningkatkan autooksidasi glukosa, asam amino dan lipid ditandai dengan peningkatan produksi MDA yang memicu kerusakan DNA, organel sel hingga jaringan makro maupun mikrovasuler, serta menyebabkan pembentukan aterosklerosis yang merupakan faktor risiko penyakit kardiovaskuler. Selain itu komplikasi yang mungkin terjadi antara lain; diabetes neuropati, diabetes nefropati, dan diabetes retinopati. ${ }^{3,4,15}$

\section{SIMPULAN}

Tidak terdapat pengaruh yang signifikan variasipemberiansnack bar ubi jalar kedelai hitam terhadap kadar SOD subjek.Snack bar ubi jalar ungu kedelai hitam dapat direkomendasikan sebagai makanan selingan bagi penderita DM tipe 2 karena memiliki kadar dan aktivitas antioksidan tertinggi di antara snack bar ubi jalar kuning maupun merah dan diharapkan dapat membantu meminimalisir stres oksidatif sehingga mampu mencegah komplikasi pada penyakit tersebut.

\section{SARAN}

Dilakukan penelitian lanjut bagaimana pengaruh konsumsi snack barubi jalar kedelai hitam terhadap parameter antioksidan darah lain seperti katalase, glutation peroksidase (GPX), dan status antioksidan total (SAT).

\section{UCAPAN TERIMA KASIH}

Puji syukur penulis panjatkan kepada Allah SWT yang telahmemberikan karunia dan kemudahan dalam menyelesaikan karya tulis ini. Terima kasih ditujukan pada PT Indofood Sukses Makmur Tbk. yang telah memberikan dana penelitian dalam program Indofood Riset Nugraha Periode 2013-2014, dan subjek penelitan yang telah memberikan partisipasi dalam uji SOD serta pihak-pihak yang telah memberikan dukungan dan bantuan sehingga penelitian ini dapat diselesaikan dengan baik.

\section{DAFTAR PUSTAKA}

1. Avianty S, Ayustaningwarno F. Kandungan Gizi dan Tingkat Kesukaan Snack bar Ubi Jalar Kedelai Hitam sebagai Alternatif Makanan Selingan Penderita Diabetes Melitus Tipe 2. Journal of Nutrition College. 2013;2(4):622-9.

2. Sabuluntika N, Ayustaningwarno F. Kadar Beta Karoten, Antosianin, Isoflavon dan Aktivitas Antioksidan pada Snack bar Ubi Jalar Kedelai Hitam sebagai Alternatif Makanan Selingan Penderita Diabetes Melitus Tipe 2. Journal of Nutrition College. 2013;2(4):689-95.

3. Waspadji S. Komplikasi Kronik Diabetes : Mekanisme Terjadinya, Diagnosis dan Strategi Pengelolaan. In: Sudoyo AW, Setiyohadi B, Alwi I, Simadibrata M, Setiati S, editors. Buku Ajar Ilmu Penyakit Dalam Jilid III. Jakarta: Pusat Penerbitan Departemen Ilmu Penyakit Dalam FKUI; 2006. p. 1884-8.

4. Laight DW, Carrier MJ, Anggard EE. Antioxidants, diabetes and endothelial dysfunction. Cardiovascular Research 2000;47:457-64.

5. Koya D, Hayashi K, Kitada M, Kashiwagi A, Kikkawa R, Haneda M. Effects of Antioxidants in Diabetes-Induced Oxidative Stress in the Glomeruli of Diabetic Rats. J Am Soc Nephrol 2003; 14:S250-S3.

6. Jawi IM, Suprapta DN, Subawa AAN. Ubi Jalar Ungu Menurunkan Kadar MDA dalam Darah dan Hati Mencit setelah Aktivitas fisik Maksimal. Jurnal Veteriner. 2008;9(2):65-71.

7. Winarsi H. Antioksidan Alami Dan Radikal. Yogyakarta: Kanisius; 2007.

8. Utari DM. Efek Intervensi Tempe terhadap Profil Lipid,Superoksida Dismutase, LDL Peroksida dan Malondialdehyde pada Wanita Menopause Bogor: IPB; 2011.

9. Nurrahman, Astuti M, Soesatyo M. Peran Tempe Kedelai Hitam dalam Meningkatkan Aktivitas Enzim Antioksidan dan Daya Tahan Limfosit Tikus terhadap Hidrogen Peroksida In Vivo. Seminar Hasil-hasil Penelitian LPPM Unimus. 2012.

10.Randox. Ransod Superoxide Dismutase. UK: RANDOX Laboratories Ltd; 2006. p. 1-2.

11.Jimoh FO, Odutuga AA, Oladiji AT. Status of Lipid Peroxidation and Antioxidant Enzymes in the Tissues of Rats Fed Low - Protein Diet. Pakistan Journal of Nutrition. 2005;4(6):431-4.

12.Sulistyo RSL. Pengaruh Pemberian Suspensi Bubuk Ubi Jalar Putih (Ipomoea batatas L.) terhadap kadar Malondialdehid (MDA), Superoksida Dismutase (SOD), dan Protein Urin 
Tikus Diabetes [Thesis]. Yogyakarta: Universitas Gadjah Mada; 2008.

13. Nizamutdinova IT, Jin YC, Chung JI, Shin SC, Lee SJ, Seo HG, et al. The anti-diabetic effect of anthocyanins in streptozotocin-induced diabetic rats through glucose transporter 4 regulation and prevention of insulin resistance and pancreatic apoptosis. Mol Nutr Food Res. 2009;11:1419-29.
14.Han KH, Sekikawa M, Shimada KI, Hashimoto M, Hashimoto N, Noda T, et al. Anthocyanin-rich purple potato flake extract has antioxidant capacityand improves antioxidant potential in rats. British Journal of Nutrition. 2006;96:1125-33.

15.Maritim AC, Sanders RA, Watkins JB. Diabetes, Oxidative Stress, and Antioxidants: A Review. J Biochem Molecular Toxicology. 2003;17(1):2438. 